\title{
Letting the readers have a say \\ Crowd theory in collection development
}

O ne of the pressing concerns for academic and research librarians is collection development, or choosing and purchasing new books for the library. Librarians spend countless hours scanning through system-recommended book titles, trying to determine which ones the students will use and benefit from as academic resources. Do students look at book covers more than at content, for instance? Do they choose books based on five-star Amazon reviews? Do they prefer books with interesting titles or interesting descriptions? Every year we do our best to decide what will be most useful for students and their research needs.

Unfortunately, the statistics are not in our favor. According to a study done in our library in $2018,{ }^{1}$ of the approximately 2.5 million books in our collection, only $52.2 \%$ have been used since 1998. This is not only the percentage of books that have been checked out, but includes how many times a student has taken a book off the shelf for in-house usage. In other words, since 1998, about 48 percent of books have never left the shelf.

These numbers don't mean that our library isn't taking steps to increase usage. In our university, a large percentage of books are filtered and bought through an approval plan, in which books are automatically purchased according to preselected criteria. Furthermore, patron driven acquisition (PDA) allows books to be purchased ac- cording to patron demand. An often-used form of PDA consists of loading unowned e-book titles into the library catalog. When patrons click on an unowned e-book, they have full access to it, and the library is charged a fee. Typically, a few uses of a book triggers an automatic purchase. There are many variations of these models, and the good thing about them is that patron input makes it less likely that the book will sit unused. One study done in our library found that "patron-driven acquisition models, when compared to traditional acquisition methods, lead the way in both use and cost-effectiveness." 2

While PDA models are generally beneficial for e-book usage, they do not as clearly solve the problem for print books. In the end, a large percentage of all books are still being purchased based on the decision of a single librarian. The study referenced above suggests that librarians "do more to solicit patron feedback and suggestions regarding how collections are built."3

Because of such low book-usage, our goal was to solicit more patron feedback in order to increase the efficacy of our collections. After the automatic purchase list and PDA books are bought, a subject librar-

Jessica Strong is BYU research assistant, email: jessicam39@gmail.com, and Quinn Galbraith is sociology and family life librarian, email: Quinn _Galbraith@byu.edu, at Brigham Young University

@ 2018 Jessica Strong and Quinn Galbraith 
ian manually filters through hundreds of system-recommended titles and purchases the ones that he or she thinks would be most useful. These were the purchases we were worried about, the ones that weren't getting any patron feedback at all, and the ones that we figured were contributing the most to such a low book usage rate.

\section{Crowd theory}

In order to better refine our purchases, we turned to crowd theory. Crowd theory is formally discussed by James Surowiecki in his book The Wisdom of Crowds, which argues that a crowd of cognitively diverse people will consistently make better decisions than one or two experts. ${ }^{4}$ We figured that a crowd likewise could be beneficial in making book purchasing suggestions, especially a crowd of potential book users.

Surowiecki qualifies, "In many . . . cases, there will be a few people who do better than the group. . . But they will not be the same [people] each time. Over [many] experiments, the group's performance will almost certainly be the best possible." ${ }^{5}$ Considering that each book purchase is a separate decision, and a single librarian potentially makes hundreds of these decisions each year, we figured that crowd feedback could be implemented in developing the "best possible" library collection.

\section{Receiving patron input}

To implement crowd theory, we decided to try something new. We started by creating a PowerPoint that included potential book purchases. Each slide had a picture of the cover of a book, the title, and a short description. We then invited students from each of three departments (Family Science, Sociology, and Social Work, respectively) to a meeting with pizza, where they could "help the library and choose books."

The departments were divided into three rooms with a PowerPoint particular to the subject area. The students were given about 15 seconds to view each slide, as we thought this would parallel a student scanning through books on a shelf or searching for them online.

We instructed the students to judge the books based on what they thought would be most useful for student needs and research in each department. Participants then rated the books on a scale of one to four based on if they thought we should buy the book.

The subject librarian also viewed the PowerPoint presentation and rated the books on the same scale. In this way we could compare what the students thought would be most beneficial with what the subject librarian thought would be best. Throughout the process we predicted that student opinion would differ from that of the librarian, and that the input of a crowd of patrons would help the librarian to choose books that would be better utilized.

We continued the process twice more throughout the year, each time with new books for students to rate. The students themselves had no expertise in purchasing books for library collections, though many had used academic books for research in their respective fields. College students were gathered from all grade levels, including a few from different majors. Each was given a separate vote according to what books they felt would best support the curriculum. According to crowd theory, multiple viewpoints and cognitive abilities are preferable. And conveniently, many students seemed excited about the prospect of having a say in the library collection (if only because of the pizza).

As we prepared to make final purchasing decisions, we averaged together student responses. The averages of the combined student ratings were then compared to the individual scores given by the librarian, allowing us to compare what the librarian would have bought versus what the students rated as important. 


\section{Results}

Although an individual librarian made the final purchasing decisions, student opinion was weighted heavily. As Surowiecki explains, crowd theory "doesn't mean that well-informed, sophisticated analysts are of no use in making good decisions. . . . It does mean that however-well-informed and sophisticated an expert is, his advice and predictions should be pooled with those of others to get the most out of him." Basically, subject librarians would most likely make good purchasing decisions on their own, but student input could help them make even better decisions. We were, in effect, trying to get "the most out of" our subject librarian.

As predicted, student input altered the librarian's final decisions. We ended up buying a few books, according to very favorable student response, that the librarian had rated as "do not purchase." We also ended up not buying certain books, based on negative student response, that the librarian had been inclined to buy.

Along these lines, another finding showed that the librarian rated books with interesting covers (here defined as having pictures of human faces) with a much greater preference than the students. This is likely because the librarian was trying to choose the books that he thought the students would be most interested in. We expected more students to choose books based on covers and were surprised to find that most were more interested in content. Clearly a librarian's understanding of student preferences isn't perfect, and student input can help a librarian to better understand their needs. What students want and what librarians think students want turned out to be quite different matters altogether.

\section{Final thoughts}

This student input-process was far from perfect. It should be noted that a librar- ian does not base his or her decisions solely on student usage, for instance. The subject librarian must also consider what resources would be beneficial to faculty members, a fact which most likely creates a gap between student and librarian preference. And while the student input seemed valuable, a future study would be necessary to determine if this input actually managed to increase the number of books used by students.

Despite all this, our process pointed out some important considerations for purchasing books. As predicted, the opinion of the crowd differed from that of the subject librarian, and this input hopefully allowed him to make better purchasing decisions. While we still grant that a single librarian choosing books based on his or her opinion is a valid method, we recommend that librarians consider implementing crowd theory principles to assist in book purchasing decisions. In this manner a librarian could potentially purchase the books that are most wanted by the readers themselves, leading to more books being used. While librarians are considered experts in their field, we believe that letting a crowd of potential readers have a say will lead to happier patrons and a more usable collection.

\section{Notes}

1. Scott Bertagnole, "HBLL Collections Utilization Report,” 2018.

2. Jared Howland, Rebecca Shroeder, and Thomas Wright, "Brigham Young University's Patron-Driven Acquisitions: Does It Stand the Test of Time?" Customer-Based Collection Development: An Overview (London: Facet Publishing, 2014).

3. Ibid.

4. James Surowiecki, The Wisdom of Crowds (2004, New York: Doubleday): 31.

5. Ibid., 5.

6. Ibid., 34.2 